\title{
Enablers and deterrents on the school-based condom availability and distribution: a scoping review
}

\author{
Mark Donald C Reñosa', Tricia Kaye F. Palola², Carl Abelardo T. Antonio ${ }^{3}$ \\ ${ }^{1}$ Research Institute for Tropical Medicine - Department of Health, Philippines, Manila, Philippines; Department of Health Policy and Administration, \\ University of the Philippines Manila, Philippines, 2 Department of Health Policy and Administration, University of the Philippines Manila, Philippines; \\ College of Nursing, University of the East Ramon Magsaysay Memorial Medical Center, Quezon City, Philippines, ${ }^{3}$ Department of Health Policy and \\ Administration, University of the Philippines Manila, Philippines; Department of Applied Social Sciences, The Hong Kong Polytechnic University, Hong \\ Kong
}

Keywords: adolescents, condom, condom availability program, school-based condom distribution

https://doi.org/10.29392/001c.12676

\section{Journal of Global Health Reports}

Vol. 4, 2020

\section{Background}

In an effort to decrease teenage pregnancies and sexually transmitted diseases, there are discussions on the implementation of a school-based condom availability and distribution policy. However, there is a dearth of information on the extent and range of the empirical evidence supporting this policy initiative. Hence, this study aimed to identify enablers and deterrents of the program to serve as groundwork for health professionals and policy makers toward a more comprehensive adolescent program in the country.

\section{Methods}

A scoping review of literature based on the five-stage framework by Arskley and O'Malley was utilized in the study. Two researchers performed a comprehensive search of peer-reviewed literature through PubMed, ScienceDirect, EBSCOhost and ProQUEST published from 1985 to 2016. Inclusion criteria for records were: i) Original research published in a peer-reviewed journal; ii) Focused on school-based condom availability and distribution; iii) Study participants were students in a secondary public or private schools; iv) Published in English language. Two researchers independently appraised each record against the set inclusion criteria. Likewise, independent abstraction of data from selected studies were performed. Disagreements in screening, selection, and abstraction were settled through consensus.

\section{Results}

A total of 2,114 records were initially screened for eligibility, of which eight met the inclusion and exclusion criteria. Seven of the studies were conducted in the USA and one study was carried-out in Mexico. Notably, none of the published papers originated in Asia. Four essential themes emerged that reinforces the program: i) establishment of state-level policy; ii) engagement of stakeholders and parents on public dialogue: iii) empowering activities in schools; and iv) increasing condom reach and coverage. On the other hand, four significant barriers were recognized; i) assumption that condom availability and distribution to adolescents promote sexual promiscuity; ii) lack of parental support due to religious and moral concerns and the acceptance of the students to certain programs; iii) discomfort and embarrassment felt in general by the students towards acquiring condoms in schools; and iv) structural barriers such as poor coverage and gender differences among male and female students.

\section{Conclusions}

These findings suggest that there have been limited studies conducted on the success and challenges of school-based condom availability program. Although study results have shown substantial benefits of the program, emergence of thematic insights relating to parental support, sexual attitude and behavior, program coverage and structural implications acted as major enablers and deterrents on condom availability and distribution program. It is crucial to recognize these existing issues to generate strategic recommendation and action for improvements of the program. 
Condom practice is extensively suggested as a birth control option to decrease probability of unintended pregnancies and as an effective barrier method to prevent sexually transmitted diseases. ${ }^{1-5}$ The inclusion of condom distribution, as well as the promotion of appropriate and consistent condom use, has been broadly integrated in existing reproductive and sexual health programs and policies in other countries. ${ }^{4}$ The unrestricted access to such prevention tools, particularly in low resource settings, contributes to efficient, cost-effective and reliable strategies against potentially detrimental health outcomes such as human immunodeficiency virus (HIV) and teenage pregnancies. ${ }^{6}$

Adolescents comprise more than $20 \%$ of the total population in Asia and although a declining trend in the youth population has been projected, Asia will still have more youth than any other region in the world by $2080 .{ }^{7}$ The adolescent age group is more predisposed to high-risk behaviors, currently representing a significant portion of sexually transmitted infections (STI) and HIV cases globally. ${ }^{8-10}$ Adolescents account for an estimated 16\% from the overall worldwide cases, with Sub-Saharan Africa and Asia being the regions with the highest number. This constant and rapid increase of cases recently has become a more important public health challenge in conservative Asia.

One of the best cases to magnify the gravity of the situation in Asia is the Philippines - being a predominantly Catholic Christian nation. The HIV/AIDS and ART Registry of the Philippines ${ }^{11}$ shows that $32 \%$ of the reported HIV cases from January 1984 to January 2019 belongs to the 15-24 age group. Moreover, the Philippines is also reported to be the only country in Asia Pacific to have a minimal reduction on its teenage pregnancy rate. ${ }^{12}$ According to the 2013 National Demographic and Health Survey, ${ }^{13}$ one in ten young Filipino women ages 15-19 have begun childbearing. In a local study by Raymundo \& $\mathrm{Cruz}^{14}$ on adolescent sexual activities, more than $23 \%$ of Filipino adolescents have engaged in premarital sex, $42 \%$ of them reporting consensual sex, $32.5 \%$ non-consensual, and $2 \%$ forced sex. They also reported that $40 \%$ of male adolescents have multiple partners other than their primary partner. Further, a funded local study by USAID also found that $69 \%$ of sexually active young men between ages 15-24 have never used condoms. ${ }^{15}$

These consequences of adolescent sexual behaviors continuously contribute to the increasing number of unwanted pregnancies and adolescent morbidities. The substantial increase in cases is attributed to restricted sex education approaches and limited access to available health services and resources. However, values and cultural factors in conservative countries in Asia greatly influence the acceptability and attitude of the community towards reproductive health programs. The context of condom use has also been bounded by misinformed health beliefs, stigma on purchasing condoms and the perspective that it is for population control rather than disease prevention. Health initiatives to implement this strategy were carried out in some Asian countries such as the Philippines but were later abolished due to these emerging moral and cultural factors.

Having identified adolescents as the target population, a "school-based condom availability and distribution program" is considered an efficient and cost-effective implementation approach to provide a broader and concentrated coverage. The provisions of this policy includes: (a) making condoms available to adolescents for free or at a reduced cost, together with proper sexual health information, (b) the program to be mandatory in a school setting and (c) obtaining parental consent as a requirement for program users. And since various intrinsic and extrinsic elements such as moral, social, physical, and financial barriers affect condom acquisition among adolescents, a school-based approach to condom availability and distribution is suggested to increase adolescent condom usage and reproductive knowledge.

While there have been some systematic reviews conducted on school-based condom distribution, most emphasized the effects of this program on adolescent condom use and sexual behavior. ${ }^{16}$ Andrzejewski and colleagues ${ }^{17}$ provided information on the acceptability condom distribution among teens in schools. However, little information exists regarding the challenges and facilitators in the implementation of school-based condom availability and distribution program especially in low- and middle-income countries, particularly in Asia. To contribute to a comprehensive discussion of this issue, we conducted a scoping review to examine and outline the extent and scope of empirical evidence on school-based condom availability and distribution. This review aims to synthesize evidence for health professionals and policy makers towards further development of a more inclusive condom distribution policy and generate strategic recommendations toward knowledge expansion, evidence-based practice and well-informed educative purposes. Also, the findings may be used as a basis for settings with similar cultural and religious influence in the context of condom use.

\section{METHODS}

We utilized the scoping review framework developed by Arksey and O'Malley, ${ }^{18}$ which ensures an iterative and reflexive way of understanding the literature extent and range. The five-step framework: i) identifying research question; ii) identifying relevant studies; iii) Study selection; iv) Charting the data; and v) Collating, summarizing and reporting the results was utilized in this review of the school-based condom distribution and availability. In the remainder of this section, we outlined the steps undertaken and actions conducted to complete the review.

\section{IDENTIFYING RESEARCH QUESTION}

We conducted a brainstorming session to develop and identify potential scoping questions focused and within the area of school-based condom distribution. The preliminary questions were sent to a subject-matter expert to evaluate its relevance and applicability. Initially, we developed three preliminary questions, which was later reduced into one focused scoping question after expert consultation. The overall question then was to determine the key enablers and deterrents affecting availability and access to condoms in schools.

Core concepts reflecting the study objectives were discussed and developed following the finalization of the scoping questions. Keywords (i.e., condom, condom use, con- 
Table 1. Electronic databases and search strings used in the study, 2017-2018

\begin{tabular}{|c|c|}
\hline $\begin{array}{l}\text { Electronic } \\
\text { database }\end{array}$ & Search string \\
\hline PUBMED & $\begin{array}{l}\text { Search }(((((()(((((\text { Condom availability) OR Condom use) OR Condom) OR Condom distribution) OR School based } \\
\text { condom distribution)) OR Contraceptive device)) AND School based)) AND (((((School based) OR School based } \\
\text { program) OR School) OR Health services) OR Health promotion)) AND (((Accessibility) OR Availability) OR } \\
\text { Distribution)) AND (((((((Teenagers) OR Adolescents) OR Males) OR Females) OR Male adolescents) OR Female } \\
\text { adolescents) OR Teens) }\end{array}$ \\
\hline ScienceDirect & $\begin{array}{l}\text { "Condom" OR "condom use" OR "contraceptive device" OR "condom distribution" OR "condom availability" AND } \\
\text { "School based" OR "school" OR "health services" OR "health programs" OR "school based programs" AND } \\
\text { "Availability" OR "distribution" OR "accessibility" OR "health promotion" AND "Adolescents" OR "teenagers" OR } \\
\text { "teens" OR "male adolescents" OR "female adolescents" OR "males" OR "females" }\end{array}$ \\
\hline EBSCOhost & $\begin{array}{l}\text { "Condom" OR "condom use" OR "contraceptive device" OR "condom distribution" OR "condom availability" AND } \\
\text { "School based" OR "school" OR "health services" OR "health programs" OR "school based programs" AND } \\
\text { "Availability" OR "distribution" OR "accessibility" OR "health promotion" AND "Adolescents" OR "teenagers" OR } \\
\text { "teens" OR "male adolescents" OR "female adolescents" OR "males" OR "females" }\end{array}$ \\
\hline ProQUEST & $\begin{array}{l}\text { "Condom" OR "condom use" OR "contraceptive device" OR "condom distribution" OR "condom availability" AND } \\
\text { "School based" OR "school" OR "health services" OR "health programs" OR "school based programs" AND } \\
\text { "Availability" OR "distribution" OR "accessibility" OR "health promotion" AND "Adolescents" OR "teenagers" OR } \\
\text { "teens" OR "male adolescents" OR "female adolescents" OR "males" OR "females" }\end{array}$ \\
\hline
\end{tabular}

dom availability, condom distribution and school-based condom distribution) were combined with index terms using Boolean operators. The final search strings for the different electronic databases were developed with the assistance of a Biomedical Librarian (see Table 1).

\section{IDENTIFYING RELEVANT STUDIES}

The two lead researchers performed all searches on March 4, 2017. Three electronic databases were used: PUBMED, ScienceDirect and EBSCOhost, to identify peer-reviewed journals relating to scope of the review. ProQUEST was also used to search for grey literature. Only studies in English and only scientific papers published from 1985 to 2016 were included. These dates reflected the emergence and further development of published literature in this area. A full list of inclusion and exclusion criteria is outlined in Table 2. A PRISMA (Preferred Reporting Items for Systematic Reviews and Meta-Analyses) diagram of the article selection process based on our criteria was developed to show systematic trimming of the retrieved records.

\section{STUDY SELECTION AND CHARTING THE DATA}

We listed down all the details, assessed and read the abstract independently and evaluated if it meets the inclusion criteria and themes emerging from the scope of the review. A spreadsheet was created to chart the information of literature, which was adapted from The Joanna Briggs Institute Reviewers' Manual. ${ }^{19}$ Details regarding publication information, study design and methodology and its sample population (if applicable) were listed, including all relevant information concerning the scoping questions were extracted. We independently completed the data extraction. Collaborative dialogue was conducted in cases where there are disagreements and discrepancies, and in order to arrive at consensus or a settlement from a third party.

\section{DATA ANALYSIS}

We used descriptive statistics to summarize all included studies. Counts and proportions were used to describe all other information. Further, we summarized key concepts from the studies related to the study scope of interest through content analysis. Each text pertaining to enablers and deterrents on school-based condom availability program were coded into manageable categories on multiple levels: words, word sense, phrase, sentence or theme. The results were then clustered according to common themes, which helped identify revealed the enablers and deterrents of the school-based condom availability program.

\section{RESULTS}

\section{DESCRIPTION OF SELECTED STUDIES}

We screened and assessed a total of 2,114 unique records for eligibility based on the set inclusion and exclusion criteria. Figure 1 outlines the screening and evaluation process used in the study. A total of 2,057 records were excluded on initial assessment of titles and abstracts. Additional 43 records were excluded after full-text assessment.

Hence, this scoping review yielded only eight studies (see summary on Table 3). Of these: majority (7 of 8; 89\%) were conducted in the United States of America and 11\% (1/ 8) was carried-out in Mexico. Notably, none of the published papers originated in Asia. All (8/8; 100\%) of the included studies used survey study designs (i.e. cross sectional survey, comparative survey, pretest and posttest survey design). The reviewed studies differed in the way they were implemented, number of participants and length of the study. Studies were conducted ranging from years 1995 to 2014 with study duration ranging from one to four years. All studies included were published as research articles in peer-reviewed journals.

We identified several reasons and factors why the schoolbased condom availability and distribution showed a rela- 
Table 2. Inclusion and exclusion criteria, scoping review, 2017-2018

\begin{tabular}{|c|c|c|}
\hline Criterion & Inclusion & Exclusion \\
\hline \multicolumn{3}{|l|}{$\begin{array}{l}\text { Types of } \\
\text { participants: }\end{array}$} \\
\hline \multirow[t]{2}{*}{$\begin{array}{l}\text { Population } \\
\text { and sample }\end{array}$} & 1. Students in a secondary public or private schools & \multirow{2}{*}{$\begin{array}{l}\text { Studies focused on teachers and/or school } \\
\text { administrators and program managers only }\end{array}$} \\
\hline & 2. Parents of the students & \\
\hline \multicolumn{3}{|l|}{ Concept: } \\
\hline $\begin{array}{l}\text { Age of } \\
\text { participants }\end{array}$ & $12-19$ years old & \\
\hline \multirow[t]{2}{*}{$\begin{array}{l}\text { Literature } \\
\text { focus }\end{array}$} & $\begin{array}{l}\text { 1. Original research and/or scientific papers where } \\
\text { themes relate to school-based condom availability and } \\
\text { distribution. }\end{array}$ & \multirow[t]{2}{*}{$\begin{array}{l}\text { Community-based implementation of } \\
\text { condom availability and distribution }\end{array}$} \\
\hline & $\begin{array}{l}\text { 2. Key factors influencing enablers and deterrents of } \\
\text { condom distribution in schools. }\end{array}$ & \\
\hline \multicolumn{3}{|l|}{ Context: } \\
\hline Time Period & 1985 to 2016 & \\
\hline Language & English & \\
\hline \multirow[t]{2}{*}{$\begin{array}{l}\text { Type of } \\
\text { article }\end{array}$} & \multirow{2}{*}{$\begin{array}{l}\text { Original research and/or scientific papers published in a } \\
\text { peer-reviewed journals (with retrievable full-text) }\end{array}$} & $\begin{array}{l}\text { 1. Articles that are editorials, research } \\
\text { summary, discussion, policy reviews or } \\
\text { personal viewpoints. }\end{array}$ \\
\hline & & $\begin{array}{l}\text { 2. Articles that are abstract only and/or no } \\
\text { retrievable full-text }\end{array}$ \\
\hline $\begin{array}{l}\text { Ethics } \\
\text { Clearance }\end{array}$ & Studies with ethics approval & \\
\hline
\end{tabular}

tive success after its implementation. Further, there are various bottlenecks that impeded and decreased the expected impact of the program. Word cloud analysis was used initially to identify emerging themes and sub-themes derived from the results of the included papers. Table 4 shows the summary of enablers and deterrents derived from the results of the included literatures. 


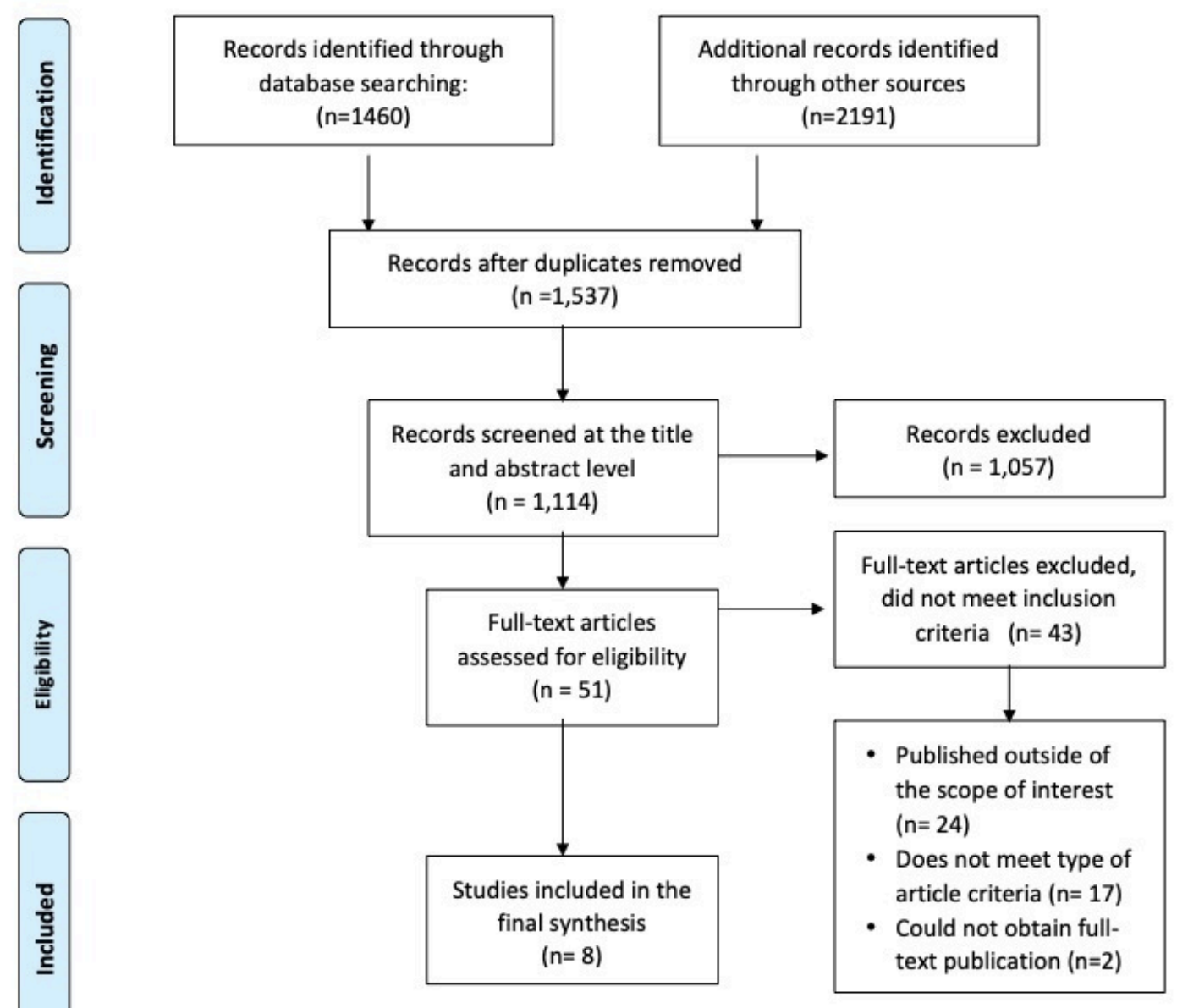

Figure 1. Literature Search Results and Study Selection, 2017-2018. 
Table 3. Summary of Included Studies in the Scoping Review, 2017-2018

\begin{tabular}{|c|c|c|c|c|c|c|c|c|}
\hline Author (s) & $\begin{array}{l}\text { Year, } \\
\text { Country } \\
\text { of origin }\end{array}$ & Aims & $\begin{array}{l}\text { Study } \\
\text { population } \\
\text { and sample } \\
\text { size }\end{array}$ & Methods & $\begin{array}{l}\text { Details of } \\
\text { intervention }\end{array}$ & $\begin{array}{l}\text { Duration of } \\
\text { the } \\
\text { intervention }\end{array}$ & Outcomes and details of these & $\begin{array}{l}\text { Key findings that relate } \\
\text { to the scoping review } \\
\text { question }\end{array}$ \\
\hline \multirow{6}{*}{$\begin{array}{l}\text { The benefits of } \\
\text { school-based condom } \\
\text { availability: cross- } \\
\text { sectional analysis of A } \\
\text { comprehensive high } \\
\text { school-based } \\
\text { program. Wolk, L. \& } \\
\text { Rosenbaum R. }\end{array}$} & \multirow{6}{*}{$\begin{array}{l}1995 \\
\text { USA }\end{array}$} & \multirow{6}{*}{$\begin{array}{l}\text { To analyze the benefits of } \\
\text { a school-based condom } \\
\text { availability program } \\
\text { relative to the risks that } \\
\text { such a program may incur. }\end{array}$} & \multirow{6}{*}{$\begin{array}{l}1,200 \text { ninth } \\
\text { through } \\
\text { twelfth } \\
\text { grade } \\
\text { students }\end{array}$} & \multirow{6}{*}{$\begin{array}{l}\text { Cross- } \\
\text { sectional } \\
\text { survey }\end{array}$} & \multirow[t]{6}{*}{ N/A } & \multirow[t]{6}{*}{1 year } & \multirow{6}{*}{$\begin{array}{l}\text { The benefit of the program by } \\
\text { aiding a sexually-active } \\
\text { student was found to be more } \\
\text { than three times as great as } \\
\text { the risk of encouraging a non- } \\
\text { sexually active student to } \\
\text { have sexual intercourse. }\end{array}$} & Enablers \\
\hline & & & & & & & & $\begin{array}{l}\text { - Active promotion and } \\
\text { engagement of faculty } \\
\text { advisors }\end{array}$ \\
\hline & & & & & & & & Deterrents \\
\hline & & & & & & & & $\begin{array}{l}\text { - Assumption that } \\
\text { condom availability } \\
\text { provides sexual activities } \\
\text { to adolescent }\end{array}$ \\
\hline & & & & & & & & $\begin{array}{l}\text { - Assumption that } \\
\text { students still use } \\
\text { substitute protection or } \\
\text { having unprotected sex. }\end{array}$ \\
\hline & & & & & & & & $\begin{array}{l}\text { Gender difference - } \\
\text { program needs to be } \\
\text { directed towards females } \\
\text { to enhance utilization }\end{array}$ \\
\hline \multirow{7}{*}{$\begin{array}{l}\text { Condom Availability } \\
\text { in New York City } \\
\text { Public High Schools: } \\
\text { Relationships to } \\
\text { condom use and } \\
\text { sexual behavior. } \\
\text { Guttmancher, S., et al. }\end{array}$} & \multirow{7}{*}{$\begin{array}{l}1997 \\
\text { USA }\end{array}$} & \multirow{7}{*}{$\begin{array}{l}\text { To examine the impact of } \\
\text { the condom availability } \\
\text { program in New York city } \\
\text { public high schools. }\end{array}$} & \multirow{7}{*}{$\begin{array}{l}7119 \\
\text { students } \\
\text { from } 12 \\
\text { selected } \\
\text { NYC schools }\end{array}$} & \multirow{7}{*}{$\begin{array}{l}\text { Cross- } \\
\text { sectional } \\
\text { survey and } \\
\text { comparative } \\
\text { study }\end{array}$} & \multirow{7}{*}{$\begin{array}{l}\text { Condom } \\
\text { availability } \\
\text { program }\end{array}$} & \multirow[t]{7}{*}{1 year } & \multirow{4}{*}{$\begin{array}{l}\text { There are equal rates of } \\
\text { sexual activity but higher } \\
\text { condom use in New York } \\
\text { schools due to its availability.. }\end{array}$} & Enablers \\
\hline & & & & & & & & $\begin{array}{l}\text { - Assembly of HIV/ AIDS } \\
\text { Team to oversee the } \\
\text { program. }\end{array}$ \\
\hline & & & & & & & & $\begin{array}{l}\text { - Teaching of minimum of } \\
6 \text { HIV/AIDS lessons in } \\
\text { each grade. }\end{array}$ \\
\hline & & & & & & & & $\begin{array}{l}\text { - Designation of a } \\
\text { resource room at school } \\
\text { where condoms and HIV/ } \\
\text { AIDS materials are } \\
\text { available. }\end{array}$ \\
\hline & & & & & & & \multirow[t]{3}{*}{$\begin{array}{l}\text { Making condoms available at } \\
\text { school does not lead to } \\
\text { increases in sexual activity }\end{array}$} & $\begin{array}{l}\text { - Arrangement of HIV/ } \\
\text { AIDS information session } \\
\text { with parents. }\end{array}$ \\
\hline & & & & & & & & Deterrents \\
\hline & & & & & & & & $\begin{array}{l}\text { - Fear that condom's } \\
\text { availability will increase }\end{array}$ \\
\hline
\end{tabular}




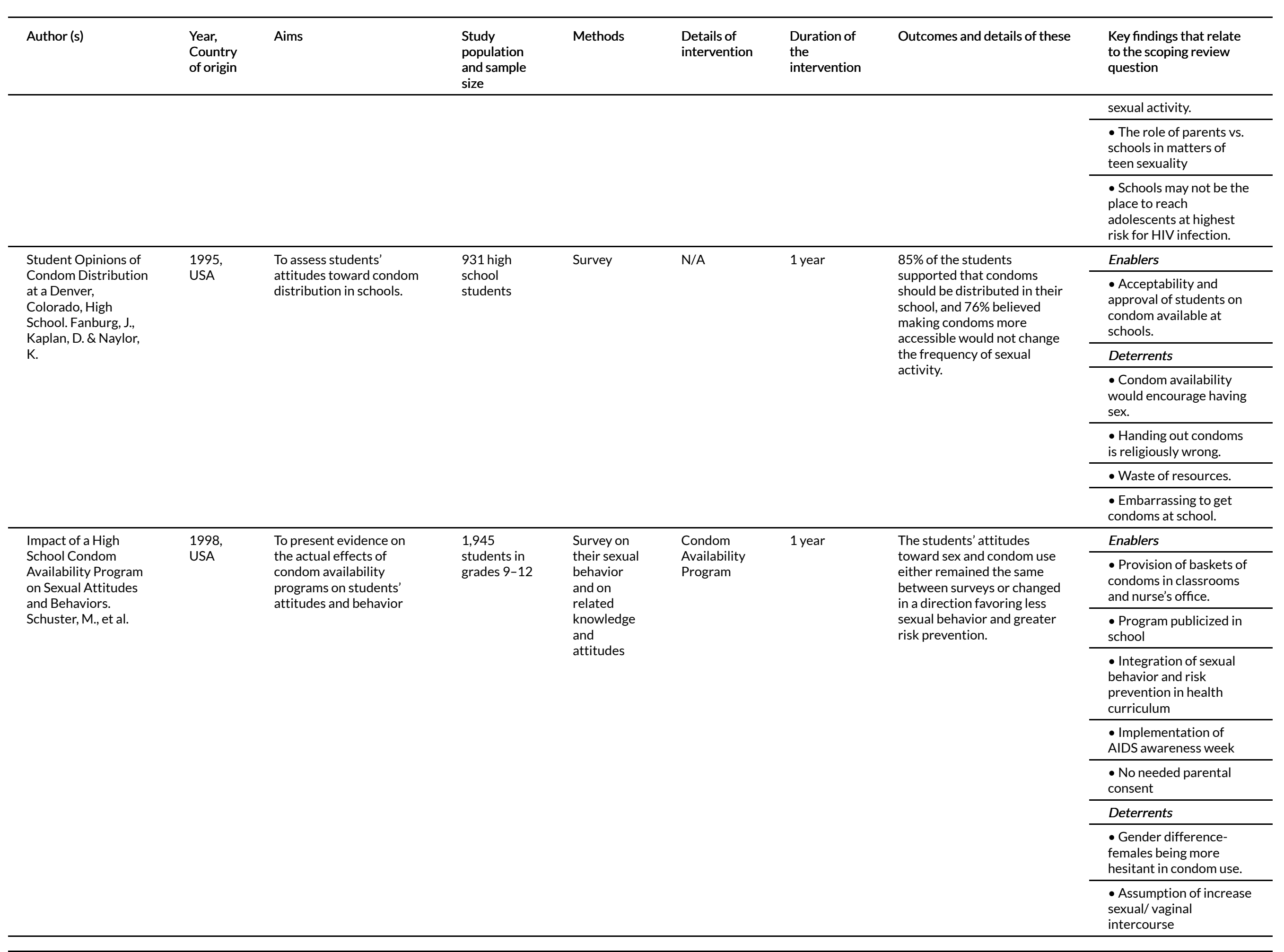




\begin{tabular}{|c|c|c|c|c|c|c|c|c|}
\hline Author (s) & $\begin{array}{l}\text { Year, } \\
\text { Country } \\
\text { of origin }\end{array}$ & Aims & $\begin{array}{l}\text { Study } \\
\text { population } \\
\text { and sample } \\
\text { size }\end{array}$ & Methods & $\begin{array}{l}\text { Details of } \\
\text { intervention }\end{array}$ & $\begin{array}{l}\text { Duration of } \\
\text { the } \\
\text { intervention }\end{array}$ & Outcomes and details of these & $\begin{array}{l}\text { Key findings that relate } \\
\text { to the scoping review } \\
\text { question }\end{array}$ \\
\hline \multirow{8}{*}{$\begin{array}{l}\text { The impact of } \\
\text { condom distribution } \\
\text { in Seattle Schools on } \\
\text { sexual behavior and } \\
\text { condom use. Kirby, D., } \\
\text { et al. }\end{array}$} & \multirow{8}{*}{$\begin{array}{l}\text { 1999, } \\
\text { USA }\end{array}$} & \multirow{8}{*}{$\begin{array}{l}\text { To measure the number of } \\
\text { condoms that student } \\
\text { obtained and subsequent } \\
\text { changes in sexual } \\
\text { behaviors and condom } \\
\text { use. }\end{array}$} & \multirow{8}{*}{$\begin{array}{l}7179 \\
\text { students in } \\
\text { pre } \\
\text { intervention } \\
\text { and } 7893 \text { in } \\
\text { post } \\
\text { intervention. }\end{array}$} & \multirow{8}{*}{$\begin{array}{l}\text { School wide } \\
\text { survey using } \\
\text { pretest and } \\
\text { posttest } \\
\text { design. }\end{array}$} & \multirow{8}{*}{$\begin{array}{l}\text { Condom } \\
\text { availability } \\
\text { program }\end{array}$} & \multirow[t]{8}{*}{2 years } & \multirow{8}{*}{$\begin{array}{l}\text { Seattle students obtained an } \\
\text { average of } 4.6 \text { condoms per } \\
\text { year from baskets and } \\
\text { vending machines available at } \\
\text { schools. }\end{array}$} & Enablers \\
\hline & & & & & & & & $\begin{array}{l}\text { - Provision of baskets of } \\
\text { free condoms and } \\
\text { vending machines with } \\
\text { minimal pay located in } \\
\text { reachable areas. }\end{array}$ \\
\hline & & & & & & & & $\begin{array}{l}\text { - Free information on } \\
\text { abstinence, condom use } \\
\text { and HIV prevention were } \\
\text { also included in the } \\
\text { baskets. }\end{array}$ \\
\hline & & & & & & & & $\begin{array}{l}\text { - No restrictions were } \\
\text { placed on students } \\
\text { obtaining condoms. }\end{array}$ \\
\hline & & & & & & & & $\begin{array}{l}\text { - Implementation of sex } \\
\text { education program } \\
\text { taught in semester-long } \\
\text { health classes. }\end{array}$ \\
\hline & & & & & & & & $\begin{array}{l}\text { - Implementation of peer } \\
\text { HIV education program. }\end{array}$ \\
\hline & & & & & & & & Deterrent \\
\hline & & & & & & & & $\begin{array}{l}\text { - Notion that condom's } \\
\text { availability will increase } \\
\text { sexual activity. }\end{array}$ \\
\hline \multirow{4}{*}{$\begin{array}{l}\text { Condom Availability } \\
\text { Programs in } \\
\text { Massachusetts High } \\
\text { Schools: } \\
\text { Relationships with } \\
\text { Condom Use and } \\
\text { Sexual Behavior. } \\
\text { Blake, S., et al. }\end{array}$} & \multirow{4}{*}{$\begin{array}{l}2003 \\
\text { USA }\end{array}$} & \multirow{4}{*}{$\begin{array}{l}\text { To determine whether } \\
\text { relationships exist } \\
\text { between the presence or } \\
\text { absence of condom } \\
\text { availability programs in } \\
\text { Massachusetts high } \\
\text { schools and adolescent } \\
\text { sexual practices. }\end{array}$} & \multirow{4}{*}{$\begin{array}{l}4166 \\
\text { students }\end{array}$} & \multirow{4}{*}{$\begin{array}{l}\text { Cross- } \\
\text { sectional } \\
\text { survey and } \\
\text { comparative } \\
\text { study }\end{array}$} & \multirow{4}{*}{$\begin{array}{l}\text { Condom } \\
\text { availability } \\
\text { program }\end{array}$} & \multirow[t]{4}{*}{1 year } & \multirow{4}{*}{$\begin{array}{l}\text { Sexual intercourse rates were } \\
\text { not higher in schools where } \\
\text { condoms were made } \\
\text { available. The presence of a } \\
\text { condom availability program } \\
\text { was protective. }\end{array}$} & Enablers \\
\hline & & & & & & & & $\begin{array}{l}\text { - State-level policy to } \\
\text { promote public } \\
\text { discussion is in placed. }\end{array}$ \\
\hline & & & & & & & & $\begin{array}{l}\text { - Public dialogue } \\
\text { between board members, } \\
\text { school administrators, } \\
\text { faculty, parents, students } \\
\text { and local community. }\end{array}$ \\
\hline & & & & & & & & $\begin{array}{l}\text { - Structural and support } \\
\text { barriers }\end{array}$ \\
\hline \multirow{3}{*}{$\begin{array}{l}\text { Improving the } \\
\text { implementation of a } \\
\text { condom availability } \\
\text { program in Urban } \\
\text { High Schools. De } \\
\text { Rosa, C. et al. }\end{array}$} & \multirow{3}{*}{$\begin{array}{l}2012 \\
\text { USA }\end{array}$} & \multirow{3}{*}{$\begin{array}{l}\text { To evaluate the } \\
\text { implementation of the } \\
\text { condom availability } \\
\text { program on students' } \\
\text { awareness and acquisition } \\
\text { of condoms. }\end{array}$} & \multirow{3}{*}{$\begin{array}{l}29,823 \\
\text { students }\end{array}$} & \multirow{3}{*}{$\begin{array}{l}\text { Survey and } \\
\text { comparative } \\
\text { study }\end{array}$} & \multirow{3}{*}{$\begin{array}{l}\text { Condom } \\
\text { availability } \\
\text { program }\end{array}$} & \multirow[t]{3}{*}{4 years } & \multirow{3}{*}{$\begin{array}{l}\text { Awareness and acquisition of } \\
\text { condoms increased } \\
\text { significantly among } \\
\text { intervention versus control } \\
\text { schools. }\end{array}$} & Enablers \\
\hline & & & & & & & & $\begin{array}{l}\text { - State-level policy on } \\
\text { condom distribution at } \\
\text { schools with mandatory } \\
\text { and flexible components. }\end{array}$ \\
\hline & & & & & & & & - Compliance and \\
\hline
\end{tabular}




\begin{tabular}{|c|c|c|c|c|c|c|c|c|}
\hline Author (s) & $\begin{array}{l}\text { Year, } \\
\text { Country } \\
\text { of origin }\end{array}$ & Aims & $\begin{array}{l}\text { Study } \\
\text { population } \\
\text { and sample } \\
\text { size }\end{array}$ & Methods & $\begin{array}{l}\text { Details of } \\
\text { intervention }\end{array}$ & $\begin{array}{l}\text { Duration of } \\
\text { the } \\
\text { intervention }\end{array}$ & Outcomes and details of these & $\begin{array}{l}\text { Key findings that relate } \\
\text { to the scoping review } \\
\text { question }\end{array}$ \\
\hline & & & & & & & & $\begin{array}{l}\text { enhancement activities } \\
\text { available in the schools. }\end{array}$ \\
\hline & & & & & & & & Deterrent \\
\hline & & & & & & & & - Low parental consent \\
\hline \multirow{6}{*}{$\begin{array}{l}\text { Feasibility and use of } \\
\text { school-based condom } \\
\text { availability programs } \\
\text { in Tijuana, Mexico. } \\
\text { Zellner JA, et al. }\end{array}$} & \multirow{6}{*}{$\begin{array}{l}2014 \\
\text { Mexico }\end{array}$} & \multirow{6}{*}{$\begin{array}{l}\text { Describes the } \\
\text { characteristics, degree of } \\
\text { satisfaction, and gender } \\
\text { differences among users } \\
\text { of a CAP implemented in } \\
\text { two high schools in } \\
\text { Tijuana (BajaCalifornia, } \\
\text { Mexico) }\end{array}$} & \multirow{6}{*}{$\begin{array}{l}570 \\
\text { students in } \\
\text { two high } \\
\text { schools in } \\
\text { Tijuana, } \\
\text { Mexico }\end{array}$} & \multirow{6}{*}{ Survey } & \multirow{6}{*}{$\begin{array}{l}\text { CAP user } \\
\text { cards and } \\
\text { survey; } \\
\text { repeat user } \\
\text { survey }\end{array}$} & \multirow{6}{*}{2 years } & $\begin{array}{l}\text { Most kiosk users were either } \\
\text { sexually active or planning to } \\
\text { have sex. }\end{array}$ & $\begin{array}{l}\text { - Provision of kiosk } \\
\text { distributing condoms }\end{array}$ \\
\hline & & & & & & & $\begin{array}{l}\text { Females were less likely to } \\
\text { request condoms and to } \\
\text { continue using the kiosk, but } \\
\text { more likely to request } \\
\text { information on other } \\
\text { contraceptive methods. }\end{array}$ & $\begin{array}{l}\text { - Setting up Information } \\
\text { kiosks on the prevention } \\
\text { of HIV and other STIs, } \\
\text { pregnancy and } \\
\text { contraception in school } \\
\text { grounds }\end{array}$ \\
\hline & & & & & & & & $\begin{array}{l}\text { - Support from non- } \\
\text { government } \\
\text { organizations }\end{array}$ \\
\hline & & & & & & & & $\begin{array}{l}\text { - Provision of } \\
\text { opportunity for } \\
\text { adolescents to gather } \\
\text { information about safe } \\
\text { sex practices and to } \\
\text { rehearse condom } \\
\text { acquisition skills. }\end{array}$ \\
\hline & & & & & & & & Deterrents \\
\hline & & & & & & & & $\begin{array}{l}\text { - Condom availability } \\
\text { may be a means of } \\
\text { initiating condom use } \\
\text { and social skills training } \\
\text { for youth who otherwise } \\
\text { would be unlikely to } \\
\text { request or obtain such } \\
\text { assistance. }\end{array}$ \\
\hline
\end{tabular}


Table 4. Summary of enablers and deterrents of the school-based condom availability program, 2017-2018

\begin{tabular}{|c|c|c|}
\hline Major themes & Sub-themes & Summary points \\
\hline \multirow{4}{*}{$\begin{array}{l}\text { Enablers of } \\
\text { condom } \\
\text { availability and } \\
\text { distribution } \\
\text { program }\end{array}$} & $\begin{array}{l}\text { Establishment of } \\
\text { state-level policy }\end{array}$ & $\begin{array}{l}\text { Mandate of state-level policy provided a comprehensive guideline in the creation } \\
\text { and implementation of condom availability and distribution programs in the school } \\
\text { setting. }\end{array}$ \\
\hline & $\begin{array}{l}\text { Engagement of } \\
\text { stakeholders and } \\
\text { parents on public } \\
\text { dialogue }\end{array}$ & $\begin{array}{l}\text { Involvement of stakeholders, school personnel and parents in the program provided } \\
\text { supportive environment for, and positive perspective of, the program }\end{array}$ \\
\hline & $\begin{array}{l}\text { Empowering } \\
\text { activities in schools }\end{array}$ & $\begin{array}{l}\text { The establishment of several empowering activities, particularly the incorporation of } \\
\text { condom distribution in HIV/AIDS and sexually transmitted diseases preventive } \\
\text { strategies among adolescents has strengthened the existing condom availability and } \\
\text { distribution program. }\end{array}$ \\
\hline & $\begin{array}{l}\text { Increasing condom } \\
\text { reach and coverage }\end{array}$ & $\begin{array}{l}\text { The establishment of condom distribution has increased the condom reach, coverage } \\
\text { and condom use of the adolescents under the program. }\end{array}$ \\
\hline \multirow{3}{*}{$\begin{array}{l}\text { Deterrents to } \\
\text { condom } \\
\text { availability and } \\
\text { distribution } \\
\text { program }\end{array}$} & $\begin{array}{l}\text { Condom } \\
\text { preconceived beliefs }\end{array}$ & $\begin{array}{l}\text { The assumption that the program promotes sexual promiscuity among adolescents } \\
\text { has been a major deterrent towards the implementation in the school setting. }\end{array}$ \\
\hline & $\begin{array}{l}\text { Exclusion and/or } \\
\text { lack of support from } \\
\text { parents and students } \\
\text { in program design }\end{array}$ & $\begin{array}{l}\text { The lack of support and acceptability of some parents and students yielded to non- } \\
\text { involvement of students in the program. }\end{array}$ \\
\hline & Gender differences & $\begin{array}{l}\text { Gender differences, behaviors and distribution sites affected the process of } \\
\text { acquiring condoms in schools and perception of condom use among adolescents. }\end{array}$ \\
\hline
\end{tabular}

\section{ENABLERS OF CONDOM AVAILABILITY AND DISTRIBUTION PROGRAM}

Overall, the program was found to have brought interventions closer to adolescents in schools. It was designed to respond to the needs of the high-risk and vulnerable population for prevention of sexually transmitted diseases and early pregnancy. Results show that the program clearly offered substantial benefits to the empowerment of adolescents in schools. The success of the program was associated with the different enablers established before, during and after its implementation.

Upon content analysis of the study results, four essential sub-themes emerged: i) establishment of state-level policy, ii) engagement of stakeholders and parents on public dialogue, iii) empowering activities in schools, and iv) enabling condom reach and coverage. The emergence of these thematic insights explicates the imperative concepts and structures that addressed the shifting needs of the students and highlights the key milestones, players and enablers that helped to scale-up the condom availability program in schools.

\section{ESTABLISHMENT OF A STATE-LEVEL POLICY}

The mandate of the state-level policy on condom distribution balances the major actors and frame of references including the context, content and processes on adolescent health. ${ }^{20,21}$ The state-level policy created an involvement of several stakeholders such as policy makers, educators, scholars, social scientists, parents and the community working toward this public health concern. As a result, it expanded the scientific and philosophical knowledge of all the stakeholders involved in the creation of the program. Making it mandatory in schools is a strategic call for the program to become more feasible and doable. Moreover, the state-level policy presented, although mandatory, has featured flexible components to address efficiency, effectiveness, equity and acceptance at the grassroots level. Blake and colleagues ${ }^{20}$ surmised that the policy, which recognizes the importance of individual family values and local culture dynamics, is essential to be acceptable. Further, provisions of the policy should clearly consider its program users and the delivery of accurate parental information to establish a positive uptake of the program. The adoption of such policies has consequently expanded the strategies against HIV and teenage pregnancy. ${ }^{20-23}$

\section{INVOLVEMENT OF STAKEHOLDERS AND PARENTS}

Several stakeholders and key players championed the mandate of condom availability and distribution in schools. The participation of the Board of Education in the development of policies has supported full adoption of a school-based approach. ${ }^{20} \mathrm{Bi}$-national non-government organizations involvement in the planning and setting up of distribution sites were also mentioned in the study of Zellner. ${ }^{24}$ The initiative of community staff and committee on AIDS and 
school district volunteers greatly assisted in the operation of the entire project in the USA. ${ }^{25}$ Physicians, particularly female and residency trained physicians also showed great support for the program. ${ }^{23}$

Moreover, the parental information component was deemed necessary to address any misinformation and assumption surrounding the program. The advocacy to strengthen information dissemination to parents has been the primordial goal of the condom availability program in two included studies. ${ }^{20,22}$ Parents as primary source of information have also failed to provide factual information due to cultural influence where sex is a taboo topic. This concern is evident on teenage pregnancy challenges within the local context such as the limited acceptability and support from the parents that create barriers to services, the usual causal relationship between access and restrictions to health services as part of a larger cycle deprivations. The existence of public dialogues among parents, educators, politicians, and other adults, as supported by the government and other non-government organizations, were important to curtail the misconceptions about human sexuality and other information related to the adolescent reproductive health. In relation to the content and delivery situated within the program and trainings, integration of parental role to facilitate the assimilation of a positive learning environment was emphasized. Blake and colleagues ${ }^{20}$ even highlighted that the program should seek recommendations from parents and students together with school administrators and faculty on specific venues for making the condoms available. By involving the parents and students in planning they become active participants and owners of the program as well, rather than mere passive recipients. Ultimately, the steadfast support of the school, parents, teachers and program providers creates a huge impact on the success of this kind of program. ${ }^{21}$

\section{ESTABLISHMENT OF VARIOUS EMPOWERING ACTIVITIES IN SCHOOLS}

Adolescent stage shows a transitional change, which poses a threat to one's identity. Majority of the studies (89\%) highlight a wide range of empowering activities. All studies have continuously improved their program exposure through and incorporation of condom distribution to HIV/ AIDS and risk prevention strategies and information dissemination. These objectives served as an operative channel for health care workers and school administrators and fostered a positive reinforcement and opportunity for students to learn about safe sex practices and to rehearse condom acquisition skills. Implementation of AIDS awareness week and national condom day activities complemented the condom availability programs ${ }^{24,26}$ These activities were focused on knowledge building putting emphasis on the prevention of risks and ensuring positive outcomes.

The empowering activities set-up in schools was coupled with compliance activities as well. De Rosa and colleagues ${ }^{21}$ have improved the delivery of services through the creation of oversight committee responsible for monitoring of dissemination of parental notifications and to maintain order and storage of condoms in schools. Some of the studies also established a provision of resource person and designated room in schools where condoms and informational activities are available ${ }^{21,22}$ Also, engaging faculty advisors and creating a positive role modeling establishes a more personal approach. ${ }^{25}$ Studies also emphasized a high-risk directed approach wherein the program can focus on sexually active students to achieve maximum benefit. Further, it was highlighted that inclusion of life skills and risk-behavior reduction pedagogies for the streamlining of information is an important consideration

\section{INCREASING CONDOM REACH AND COVERAGE}

Majority of the studies included (63\%) have devised several strategies that increase the reach and coverage of the program. Three out of five studies have included a provision of condoms in easy access location. Schuster ad colleagues ${ }^{26}$ provided baskets of condoms in classrooms and nurse's office that offers solution to structural barriers. Meanwhile, provision of 2-6 baskets of free condoms and vending machines with minimal pay at US\$0.25 each, located in clinic reception areas, examination areas and clinic bathrooms were also innovative solutions making condoms available without barriers in school. ${ }^{27}$ Each basket is filled with free information on abstinence, condom use and HIV prevention to encourage acquisition of skills as well. Zellner and colleagues, ${ }^{24}$ on the other hand, provided kiosk for condom distribution in school grounds coupled with information dissemination.

Two out of eight studies also placed no restrictions in acquisition of condoms. ${ }^{26,27}$ The program does not put a limit on the number of condoms students can obtain, does not require prior counseling, and does not require prior permission for condom accesss. It is also interesting to note that the program mentioned in these two studies also do not require parental consent to acquire condoms in schools. In turn, the students become comfortable to reach for condoms and do not feel embarrassed to ask for condoms. This system of reach and coverage points to new ways to engage students for effective partnership.

\section{DETERRENTS IN THE CONDOM AVAILABILITY AND DISTRIBUTION PROGRAM}

This scoping review also presented deterrents before, during and after the implementation of the school-based condom availability and distribution program, which limits the accomplishment of the program's objectives. Three significant sub-themes were identified: (1) Condom preconceived beliefs and misnomers, (2) Unsupportive and non-inclusion of parents and students to program design, and (3) Gender differences. Through recognition of these existing issues, researchers were able to determine several recommendations to reinforce access and scalability of the program.

\section{CONDOM PRECONCEIVED BELIEFS}

Majority of the studies reported general notions linking condom availability and distribution programs to adolescent sexual behaviors. Arguments have existed even before implementation of their studies associating school-based condom distribution to promotion and encouragement of 
sexual activities, particularly vaginal intercourse among teenagers. ${ }^{22,23,25-27}$ These studies have examined the relationship of the program strategy and sexual behavior among adolescents. Overall results implied that sexual activities are not significantly affected by the availability of condoms.

Schuster and colleagues ${ }^{26}$ reviewed and analyzed the changes in the sexual activity patterns of the sexually active recipients of the program in there target population using baseline and follow up surveys. Results showed that among 1,945 grade $9-12$ students, $76 \%$ had no changes in the frequency of sex, $19 \%$ believed would have sex more often, and $5 \%$ believed would have sex less often, while females answered slightly more frequently than males that giving out condoms would not change sexual frequency (81\% versus $72 \%)$. Statistical analysis also indicated no significant change between the baseline and the follow-up surveys in the percentage of males or females who had ever had vaginal intercourse or who had had vaginal intercourse during the prior year of the implementation.

Kirby and colleagues ${ }^{27}$ in a study in ten high schools in Seattle, USA reviewed supporters and opponents of condom distribution. Results showed that the percentage of students who had ever had sex, relative to the program implementation, has decreased marginally from $46 \%$ to $42 \%$, while it remained stable at about $49 \%$ to $50 \%$ nationwide. Moreover, schools without health centers also displayed a statistically significant decrease in the percentage of students who had ever had sex relative to the change over time. Results further indicate that condom distribution did not hasten other measures of sexual activity.

In a comparative study between New York and Chicago students in the USA, the rate of increase of sexual activity associated with age among new students was the same in both cities. ${ }^{22}$ Blake and colleagues ${ }^{20}$ also provided substantial evidence stating that adolescents enrolled in such programs were less likely to be sexually active or to report recent sexual intercourse. They also rejected the association of age with sexual behavior and condom acquisition. More importantly, the study emphasized that the presence of a condom availability program was more of a protective approach.

The assumption that student still uses substitute protection has also emerged. In a benefit-risk analysis conducted among sexually active and inactive twelfth grade students, results still showed a significant number of students who would still perform unprotected sex even during the implementation of the program. ${ }^{25}$

\section{LACK OF PARENTAL SUPPORT AND STUDENT ACCEPTANCE}

Some of the studies have presented issues regarding the lack of parental support for, and student acceptance of, the program. According to Wolk and colleagues, ${ }^{25}$ less than 20 students each year were not permitted by their parents to participate in the program. Persisting issues on the role of parents as against schools in sexuality matters have also slowed down approval of such programs in schools. ${ }^{22}$ Thus, reinforcement of condom distribution was made in conjunction with AIDS education and prevention in high schools. Data from Guttmacher and colleagues ${ }^{22}$ showed that regardless of extensive disapproval, $69 \%$ of parents, $89 \%$ of students, and $76 \%$ of teachers support condom distribution. Blake and colleagues ${ }^{20}$ also highlighted the importance of parent involvement in dialogues and debates, as well as active parental consensus to provide program awareness and success.

A substantial consideration of the student acceptability of the program was also derived from the studies. Religious and moral beliefs were also considered as a factor in effective implementation. In 931 high school students surveyed by Fanburg and colleagues, ${ }^{23} 21 \%$ were not in favor of the condom distribution because they perceive it as "religiously wrong”. Guttmacher and colleagues ${ }^{22}$ have identified reasons for non-acceptance of student which included the following: i) students consider it as a waste of resources if they do not use it every time they have sex; ii) females recognize it as a waste of time handing out condoms because they don't intend to use it regardless of availability; iii) not against condoms, but believes that schools are not the right place for distribution; and iv) lower grade students disproportionately believe that they should not have sex unless they are older or married.

\section{CONDOM ACQUISITION AND UTILIZATION}

Gender differences among males and females and adolescent behaviors affected program coverage and utilization as well. Females tend to be more embarrassed when obtaining condoms and are not comfortable proposing condom use to partners. ${ }^{21,26}$ They are also less likely to report condom use, making the recorded number of female participants' condom acquisition lower than male participants. ${ }^{21}$ Women are also inclined to choose other methods of contraception that they perceive to be more effective or more convenient than condoms. ${ }^{25}$ Further development may be necessary to enhance utilization of the program, especially directed to females, given that the female population are more likely to visit school-based health services. ${ }^{25}$

Students also reported discomfort and embarrassment in acquiring condoms inside school premises. The site of distribution was a major consideration for students to obtain condoms. Program users have recommended that condoms should be distributed instead from "machines in bathrooms" (45\%) or from the "school nurse" (42\%) while other students also suggested to obtain condoms from "other students" (8\%) and "teachers" (5\%). ${ }^{23}$ Some programs delivered condoms through designated kiosks, condom baskets in classroom, nurses' offices, vending machines, bathrooms and clinic receptions. ${ }^{24,26,27}$ Thus, it can be concluded that situational factors in condom acquisition need to be addressed by program managers to increase condom utilization among adolescents.

\section{DISCUSSION}

This scoping review to the best of our knowledge was the first to identify the enablers and deterrents of the schoolbased condom availability and distribution program. This paper represents a comprehensive summary of the published literature on successes and challenges of condom 
availability and distribution program within the school setting. This paper recognizes that the increasing vulnerability and exposure of adolescents to HIV/AIDS and teenage pregnancy is an issue of interest to stakeholders responsible in refining the progress of the condom reach and coverage. Key finding suggest that there was an overall paucity of evidence on the implementation of the program and that no studies were conducted in Asia. Majority of the research were only conducted in the USA and Mexico, despite the multifaceted search strategy utilized in this review. The absence of available evidences in Asia suggests that although most of the countries are experiencing increase of HIV/AIDS and teenage pregnancy incidence, school-based condom availability program have not been a priority research area. The limited studies published on this issue also underscores a challenging aspect of understanding the extent of acceptability and effectiveness of the approach, i.e. cultural appropriateness. The model for service provision also appears to be less understood.

The enablers of the program were mainly hinged on the presence and establishment of the state-level policies. In fact, studies urged different stakeholders to sit down and begin to talk together regarding school-based approach implementation to address the changing needs of the adolescents. The included studies also highlighted the critical component of partnering and communicating for both the future of sexuality education and adolescent care. Strengthening the collaboration between academia and service in the preparation of adolescent is imperative strategy for all education and health service institutions. The initiative of involving the parents provides a framework on how the students are being prepared in all aspects of their development. ${ }^{28,29}$ Further, the values and roles that were acknowledged have contributed to the success of the implementation of the program.

Adolescent's health is at risk due to lack of accurate and appropriate information and incomplete understanding of the many aspects of sexual behavior and reproductive health. ${ }^{10}$ They also have inappropriate knowledge to protect them, and are often unaware of how to access the information on available health services. The studies have explicated that schools, together with the parents and communities, has a major role to orient the teenagers on the possible risk behaviors that they may develop because of those extenuating factors. It has to be understood that schools have the moral responsibility to develop their students into wellinformed and holistic individuals and productive citizens. As teachers pursue to achieve a soul in accordance with virtue, they must be more inclined to provide quality learning environments and be an advocate for what is true and what is just, and more importantly, offer oneself to a more caring world bounded with all the rights to choose $\mathrm{e}^{30}$ The provision of trainings to teachers in understanding adolescent sexuality, as most of the health services often not meeting the special needs of adolescents in terms of confidentiality, privacy, cost and acceptability has positive effects to the overall performance of the program. Positive synergies of integrating creative mechanisms (i.e. distribution locations) are noted in the included studies that increase the reach and acquisition of condoms.

The literature, however, is almost unanimous in identify- ing significant barriers across the included studies. The assumption that the program will encourage sexual promiscuity significantly hampers the delivery and acceptance of condom use. In this respect, the science employed in the program should embody the practice of an equally, or more powerful science. Uniting efforts, the intelligent use of information, technology, processes and structures may play perfect solutions in advancing overall goal. ${ }^{31,32}$ By virtue of putting balance between science and religion or other personal mores, the government should untiringly explain to the families and communities that although the ideologies of abstinence should be upheld, provisions of specific measures for high-risk adolescents are imperative. ${ }^{28}$ The major actors should rethink of bringing in life skills and risk-behavior reduction pedagogies as the main focus of streamlining of information. The major actors and families need to agree to disagree and find a thin line of solutions to teaseout differences to increase support and acceptability. Yet, new health system landscape requires more than this, it also demands new attitudes in appreciating and looking for ways to engage in effective partnerships with both community and government. The social media platform must also be considered especially in the dissemination of correct and factual information as regards to adolescent health and development.

Framing of the condom availability program is also important in advancing the overall goal. All of the included studies focus mainly on decreasing the incidence of HIV/ AIDS infection, rather than teenage pregnancy. Each country must consider multiplicity of factors associated with the miso-meso-macro environment where a policy is developed. By having such, the inception of policies is culled based on the needs of the society and the people governed. Also, there is no better way to approach the changing paradigm shifts of adolescent health than to have a growing assimilation of scientific evidence. Researchers must contribute to increasing the body of literature concerning the integrative model of school-based condom availability program perspectives within local contexts.

\section{REVIEW STRENGTHS AND LIMITATIONS}

While the literature synthesized in this scoping review was limited to our inclusion criteria, the researchers assert that the paper maintains academic rigor, trustworthiness and transparency. The assistance of a Biomedical Librarian in finalizing the search strategy further validates research rigor. Although the researchers believed that the exhaustive search terms utilized in this review captured the relevant publications within the scope of interest, we might have missed other relevant studies that were not published in the databases used. Searching other databases may have generated additional studies, which may affect the our findings and conclusions on the success and impact of the schoolbased condom availability program.

\section{CONCLUSION}

This scoping review demonstrates the range and extent of literature on the empirical evidence of the school-based condom availability program. Although there has been in- 
sufficient research included in this review, several enablers and barriers were identified. This review concludes that future operational research should be conducted in a local setting to explore implementation processes and acceptability. The researchers hope that the results of the study may spur further research in this field, and contribute to policy development. Complex as it is, this suggests a deeper social problem that should be addressed.

Acknowledgements: We would like to acknowledge and thank the support of Department of Health Policy and Administration, University of the Philippines- Manila. This study was registered (RGAO-2017-0137) to Research Grants Administration, University of the Philippines Manila. Ethics approval was not required.

Funding: None.

Authorship contributions: Conceived and conceptualized the study: $M D R, T K P$ and CTA. Performed research database search and data analysis: $M D R$ and TKP. Prepared the initial draft of the manuscript: $M D R$ and TKP. CTA contributed to the report writing and critically reviewed the manuscript. All authors read and approved the final manuscript.

Competing Interests: The authors have completed the Unified Competing Interest form at www.icmje.org/coi disclosure. pdf (available on request from the corresponding author) and declare no conflicts of interest.

\section{Correspondence to:}

Dr. Mark Donald Reñosa

Research Institute for Tropical Medicine

9002 Research Drive

Filinvest Corporate City

Alabang

Muntinlupa City

Philippines 1781

drmarkdonaldrn@gmail.com

This is an open-access article distributed under the terms of the Creative Commons Attribution 4.0 International License (CCBY-4.0). View this license's legal deed at http://creativecommons.org/licenses/by/4.0 and legal code at http://creativecommons.org/licenses/by/4.0/legalcode for more information. 


\section{REFERENCES}

1. Warner L, Clay-Warner J, Boles J, Williamson J. Assessing condom use practices. Implications for evaluating method and user effectiveness. Sex Transm Dis. 1998;25:273-277. doi:10.1097/0000743 $\underline{\text { 5-199807000-00001 }}$

2. Beyeza-Kashesya J, Kaharuza F, Ekstrom AM, Neema S, Kulane A, Mirembe F. To use or not to use a condom: A prospective cohort study comparing contraceptive practices among HIV-infected and HIVnegative youth in Uganda. BMC Infect Dis. 2011;11:144. doi:10.1186/1471-2334-11-144

3. Cates W Jr, Stone KM. Family planning, sexually transmitted diseases and contraceptive choice: A literature update-Part I. Fam Plann Perspect. 1992;24:75-84. doi:10.2307/2135469

4. Hearst N, Chen S. Condom promotion for AIDS prevention in the developing world: Is it working? Stud Fam Plann. 2004;35:39-47.

5. Warner L, Gallo M, Macaluso M. Condom use around the globe: How can we fulfil the prevention potential of male condoms? Sexual Health. 2012;9:4-9.

6. Crosby R, Cates W Jr. Condom use: Still a sexual health staple. Sexual Health. 2012;9:1-3. doi:10.1071/ $\underline{\mathrm{SH} 11111}$

7. Nations U. Youth population trends and sustainable development. United Nations, Department of Economic and Social Affairs, Population Division. 2015.

8. Witwer E, Jones R, Lindberg L. Sexual Behavior and Contraceptive and Condom Use Among U.S. High School Students, 2013-2017. New York: Guttmacher Institute; 2018. doi:10.1363/2018.29941

9. Brown JD, Strasburger VC. From Calvin Klein to Paris Hilton and MySpace: Adolescents, sex, and the media. Adolesc Med State Art Rev. 2007;18:484-507, vi-vii.

10. WHO WHO. Adolescent Pregnancy: Issues in Adolescent Health and Development. Geneva, Switzerland: World Health Organization; 2004.

11. DOH DoH. HIV/AIDS and ART Registry of the Philippines Report. 2016.

12. UNFPA UNPF, UNESCO UNESaCO, WHO WHO. Sexual and Reproductive Health of Young People in Asia and the Pacific: A Review of Issues, Policies and Programmes. Bangkok: Thailand: UNFPA; 2015.
13. PSA PSA, International I. Philippines National Demographic and Health Survey 2013. Manila, Philippines, and Rockville, Maryland, USA: PSA and ICF International; 2014.

14. Raymundo C, Cruz GT. Youth Sex and Risk Behaviors in the Philippines. Manila, Philippines: Demographic Research and Development Foundation and University of the Philippines Population Institute; 2004.

15. Ramos-Jimenez P, Lee R. Male Sexual Risk Behavior and HIV/AIDS: A Survey in Three Philippine Cities. Manila, Philippines: De La Salle University; 2007.

16. Wang T, Lurie M, Govindasamy D, Mathews C. The Effects of School-Based Condom Availability Programs (CAPs) on Condom Acquisition. Use and Sexual Behavior: A Systematic Review AIDS Behav. 2018;22:308-320. doi:10.1007/s10461-017-1787-5

17. Andrzejewski J, Liddon N, Leonard S. Condom Availability Programs in Schools: A Review of the Literature. Am J Health Promot. 2019;33:457-467. do i:10.1177/0890117118791118

18. Arksey H, O’Malley L. Scoping studies: Towards a methodological framework. International Journal of Social Research Methodology. 2005;8:19-32. doi:10.1 $\underline{080 / 1364557032000119616}$

19. Institute TJB. Joanna Briggs Institute Reviewers' Manual: 2015 Edition / Supplement. The University of Adelaide, South Australia; 2015.

20. Blake SM, Ledsky R, Goodenow C, Sawyer R, Lohrmann D, Windsor R. Condom availability programs in Massachusetts high schools: Relationships with condom use and sexual behavior. Am J Public Health. 2003;93:955-962. doi:10.2105/AJ PH.93.6.955

21. De Rosa CJ, Jeffries RA, Afifi AA, Cumberland WG, Chung EQ, Kerndt PR, et al. Improving the implementation of a condom availability program in urban high schools. J Adolesc Health. 2012;51:572-579. doi:10.1016/i.jadohealth.2012.03.01 $\underline{0}$

22. Guttmacher S, Lieberman L, Ward D, Freudenberg N, Radosh A, Des Jarlais D. Condom availability in New York City public high schools: Relationships to condom use and sexual behavior. Am J Public Health. 1997;87:1427-1433. doi:10.2105/AJPH.87.9.1427 
23. Fanburg JT, Kaplan DW, Naylor KE. Student opinions of condom distribution at a Denver, Colorado, high school. J Sch Health. 1995;65:181-185. doi:10.1111/j.1746-1561.1995.tb06226.x

24. Zellner JA, Martinez-Donate AP, Hovell MF, Sipan CL, Blumberg EJ, Carrizosa CM, et al. Feasibility and use of school-based condom availability programs in Tijuana, Mexico. AIDS Behav. 2006;10:649-657. doi:1 $\underline{0.1007 / \mathrm{s} 10461-006-9105-7}$

25. Wolk LI, Rosenbaum R. The benefits of schoolbased condom availability: Cross-sectional analysis of a comprehensive high school-based program. $J$ Adolesc Health. 1995;17:184-188. doi:10.1016/1054-1 39X(95)00031-M

26. Schuster MA, Bell RM, Berry SH, Kanouse DE. Impact of a high school condom availability program on sexual attitudes and behaviors. Fam Plann Perspect. 1998;30:67-72,88.

27. Kirby D, Brener ND, Brown NL, Peterfreund N, Hillard P, Harrist R. The impact of condom availability [correction of distribution] in Seattle schools on sexual behavior and condom use. Am J Public Health. 1999;89:182-187. doi:10.2105/AJPH.89.2.182
28. Tarkang EE. Perceived family support regarding condom use and condom use among secondary school female students in Limbe urban city of Cameroon. BMC Public Health. 2014;14:173. doi:10.1186/1471-2 458-14-173

29. Tipwareerom W, Weglicki L. Parents' knowledge, attitudes, behaviors, and barriers to promoting condom use among their adolescent sons. Nursing and Health Sciences. 2017;19:212-219. doi:10.1111/n $\underline{\text { hs. } 12331}$

30. Ma ZQ, Fisher MA, Kuller LH. School-based HIV/ AIDS education is associated with reduced risky sexual behaviors and better grades with gender and race/ethnicity differences. Health Educ Res. 2014;29:330-339. doi:10.1093/her/cyt110

31. Naswa S, Marfatia YS. Adolescent HIV/AIDS: Issues and challenges. Indian J Sex Transm Dis AIDS 2010;31:1-10. doi:10.4103/0253-7184.68993

32. Boonstra H. Young People Need Help in Preventing Pregnancy and HIV; How Will the World Respond? Guttmacher Policy Review. 2007;10. 